\title{
Regeneration after wildfire in communities dominated by Pinus pinaster, an obligate seeder, and in others dominated by Quercus pyrenaica, a typical resprouter
}

\author{
L. Calvo*, S. Santalla, E. Marcos, L. Valbuena, R. Tárrega, E. Luis \\ Area de Ecología, Facultad de Biología, Universidad de León, 24071 León, Spain
}

Received 1 August 2002; received in revised form 21 January 2003; accepted 23 March 2003

\begin{abstract}
The effects of wildfire on vegetation regeneration in communities dominated by Quercus pyrenaica and those dominated by Pinus pinaster in NW Spain were compared. In order to study changes in the composition and structure of both types of community, permanent plots were established in areas dominated by $Q$. pyrenaica and those dominated by $P$. pinaster. All were burned by wildfires at the end of summer. In each plot a permanent transect of $20 \mathrm{~m} \times 1 \mathrm{~m}$ was established. Basal cover of the plant species present was analysed. In both types of community the global cover values generally increased throughout the study period. In the oak communities the species that appear in the first years are those that will dominate in the mature stage, like $Q$. pyrenaica and Erica australis. Both species are typical resprouters: from shoots on the rhizome or the stem of subterranean roots in the case of Q. pyrenaica and from lignotubers in the case of E. australis. Among the other species, herbaceous perennials dominated during the first year after the fire, Luzula lactea being the most representative. The percentage of bare soil decreased very rapidly after the first year of regeneration. However, in the P. pinaster communities the species that appeared with higher cover values during the first and second year after fire were seeders, like P. pinaster and Halimium alyssoides. Other species that appeared in these communities were Chamaespartium tridentatum, and E. australis. Amongst the herbaceous perennials, the most representative species was the Liliacea Ornithogalum umbellatum, which appeared throughout the study period in all the burned plots. The percentages of bare soil were higher than in the oak communities. Structural parameters such as diversity and specific richness were much higher in the community dominated by oak than in the pine stand. In general, regeneration after wildfire in the Pinus community was slower than in oak communities.
\end{abstract}

(C) 2003 Elsevier Science B.V. All rights reserved.

Keywords: Wildfire; Regeneration; Adaptive traits; Species diversity

\section{Introduction}

Quercus pyrenaica is one of the most abundant and characteristic oak species in the Iberian Peninsula. In Spain, the main areas covered by this species are found

\footnotetext{
* Corresponding author. Tel.: +34-987-291567; fax: +34-987-291501.

E-mail address: deglcg@unileon.es (L. Calvo).
}

in León province, where they cover $20 \%$ of the total surface area (Luis and Tárrega, 1993). Nowadays, this large area has significantly decreased because of human action, mainly forest fires (Calvo et al., 1991, 1999). Approximately $40 \%$ of the total forested area burned in the province of León is covered by $Q$. pyrenaica forest (Velez, 2000). Other communities widely distributed in León province are those occupied by Pinus sp., which are mostly plantations. 
Amongst these, a natural Pinus pinaster community, originally covering 11,500 ha, is notable. Due to its high resin content, $P$. pinaster is one of the most pyrophytic species among the Spanish conifers (Velez, 2000). Fires have occurred frequently in this community, generally affecting small areas and mostly caused by dry spring-summer storms. However, in September 1998 there was a large-scale fire, which burned more than 3000 ha. Due to the frequency of fires in this area, the anatomical and physiological characteristics of this population distinguish it from any other natural population of $P$. pinaster in the Iberian Peninsula. There are two aspects to be considered here: the large number of fires occurring and the extraordinary capacity for recovery, with up to almost two million seedlings per hectare found after the fire (Tapias et al., 1998).

The recovery capacity and speed of both types of community basically depends on the regeneration strategy of the species present. $Q$. pyrenaica is a typical resprouter, regenerating from shoots on the rhizome or the stem of subterranean roots (Calvo et al., 1991; Luis-Calabuig et al., 2000). The resprouting capacity of this species is shared by others of the genus Quercus, distributed over the Mediterranean area, including Quercus coccifera (Trabaud, 1980; Lloret and Vilá, 1997) and Quercus ilex (Pausas and Vallejo, 1999). However, their germination capacity in the field is low.

In the other type of community, $P$. pinaster is an obligate seeder (Martínez-Sánchez et al., 1995). The advantage of germination is that it increases the genetic variability and stability of the populations (Baskin and Baskin, 1998). However, obligate seeders in general are at a disadvantage in comparison with species that can sprout vegetatively so occupy the area more quickly (Naveh, 1975; Trabaud, 1987). Therefore, it is apparent that one of the most important factors influencing post-fire regeneration is the type of species existing prior to fire in each community.

Another aspect influencing the speed of regeneration after a fire is the time of year when it occurs, as this determines the intensity and severity of the fire. Several authors (Trabaud, 1980; Ohmann and Grigal, 1981; Allen and Partridge, 1988) have examined the importance of the season of fire in recovery processes. In general, these authors state that fires occurring at the end of summer or at the beginning of autumn cause greater damage to the ecosystem and this can be directly attributed to the increase in plant flammability after the low rainfall period and the high temperatures reached by the fire. In the study areas most fires and, of course, the most intense ones occur at the end of summer (Velez, 2000).

The main aim of this study was to analyse the differences in plant recovery capacity after summer fires in different types of communities: three dominated by a typical resprouter- $Q$. pyrenaica-and others dominated by an obligate seeder- $-P$. pinaster.

\section{Materials and methods}

The study of post-fire regeneration was carried out in different zones burned by summer wildfires. $Q$. pyrenaica communities occupied three study zones: Q1, Q2, Q3. These areas are situated in the north of León province (NW Spain). The first study zone Q1, was burnt by a wildfire in September 1985 and is situated in an area with almost no slope, at an altitude of $1150 \mathrm{~m}$ (UTM coordinates: 30TUN243292). The second study zone Q2, was burnt by a wildfire in August 1986 and is situated on a north-facing area with a steep slope, at an altitude of $950 \mathrm{~m}$ (UTM coordinates: 30TUN982305). The third study zone Q3, was burnt by a wildfire in August 1989 in an area with almost no slope, at an altitude of $950 \mathrm{~m}$ (UTM coordinates: 30TUN035305).

The other study area was located in a $P$. pinaster stand in the Sierra del Teleno, León province (NW Spain) (UTM 29TQG2984), at an approximate altitude of $1100 \mathrm{~m}$. This is a natural $P$. pinaster stand, in which 3000 ha was burned by a wildfire in September 1998. We marked three permanent plots: P1, P2, P3, in this extensive surface. Each plot is characterised as follows-Plot 1: Gentle slope and north-facing (UTM 29TQG312839); Plot 2: Situated on a gentle slope with S-W exposure (UTM 29TQG319825); Plot 3: Situated on a marked slope with N-W exposure (UTM 29TQG324819).

According to Rivas (1987) all these communities, dominated by $Q$. pyrenaica and dominated by $P$. pinaster, have a Mediterranean climate with 2-3 months' dryness in summer and annual precipitation between 550 and $900 \mathrm{~mm}$; mean annual temperature is $10.9{ }^{\circ} \mathrm{C}$. The soil is classified as a cambisol (Junta de 
Castilla y León, 1987). According to granulometric analysis, the soils in these areas are very sandy and acidic ( $\mathrm{pH}=5.5)$ (Calvo et al., 1998a).

From a phytosociological viewpoint all the study areas are dominated by $Q$. pyrenaica or $P$. pinaster and belong to a vegetation series dominated by $Q$. pyrenaica (Penas et al., 1995).

In each area $(\mathrm{Q} 1, \mathrm{Q} 2, \mathrm{Q} 3$ and $\mathrm{P} 1, \mathrm{P} 2, \mathrm{P} 3)$ a permanent plot of $20 \mathrm{~m} \times 1 \mathrm{~m}$ was established. In each plot, twenty $1 \mathrm{~m}^{2}$ quadrats were studied during the first, second and third years after burning. However, area Q3 was studied 3 months, 1 and 2 years after a wildfire because there was a new disturbance during the third year of regeneration so the study here was halted. In each sampling unit percentage cover of all the species present (herbaceous and woody) were visually estimated, in addition to the percentage of bare soil. This sampling method has been used in many studies of regeneration after fire (Calvo et al., 1998a; Tárrega et al., 1995, 1997).

The climate of the study areas has been characterised using data from the Boñar Meteorological Station for zone Q1; the Virgen del Camino Meteorological Station for zones Q2 and Q3 zones and Tabuyo Meteorological Station for plots P1, P2 and P3.

\subsection{Data analyses}

The data obtained were used to calculate the percentage cover of the different life forms (annual herbs, perennial herbs and woody species). The Shannon diversity index $\left(H^{\prime}\right)$ (Shannon and Weaver, 1949) and the evenness index $\left(J^{\prime}=H^{\prime} / H^{\prime} \max\right.$ ) (Pielou, 1969) were determined from the mean cover values for each community. Correspondence Analysis (Hill, 1974) (CA, statistical package CANOCO, Ter Braak, 1991) was used to relate regeneration in Quercus and in Pinus communities in time after burning. In order to determine whether the regeneration tendencies were common to both types of community or not, the species were not used as variables (as they were different), however, mean values of the woody, annual and perennial species cover and bare soil, and the number of woody, annual and perennial species of each community and each year of study were used in this analysis.

Bare soil and woody, perennial and annual cover values were compared by two factor repeated measures of analysis of variance (site and time after fire, repeated measure), and also species diversity, richness and evenness values. In order to detect possible differences between the two types of community (Pinus and Quercus) over time, the percentages of life forms (woody, perennial and annual herbs) were compared by two factor repeated measures of analysis of variance (site and time after fire, repeated measure). The Scheffe (1959) test was used to detect any significant differences $(P<0.05)$. The David et al. (1954) test was used to check the normality and the Cochran (1941) test to check the homocedasticity.

In order to analyse the possible effects of weather conditions on the regeneration patterns observed in the different areas, data on annual precipitation $(\mathrm{mm})$ and mean annual temperature $\left({ }^{\circ} \mathrm{C}\right)$ from the study areas were analysed. The mean and standard deviation for the precipitation and mean annual temperature records have been calculated for a period of 28 years at each meteorological station used to characterise the study zones. This allows us to determine whether mean annual precipitation and mean annual temperature in the years when fires occurred and post-burning deviate from mean values. Plant nomenclature follows Tutin et al. (1964-1980).

\section{Results}

In order to determine whether the weather variables from the different sites and years influence the recovering vegetation composition, mean annual precipitation and mean temperature were described in Fig. 1. This figure represent the mean and standard deviation of both parameters from each meteorological station used to characterise the study zones (Mean Q1, Mean Q2, Mean Q3, Mean P), thus representing the precipitation and temperature values for each zone in the year of burning and in years 1, 2 and 3 after the fire.

Mean temperature values (Fig. 1a) are very similar in the different study zones, with a mean variation of $10{ }^{\circ} \mathrm{C}$ in zones $\mathrm{Q} 1$ and $\mathrm{P}$ to $10.8{ }^{\circ} \mathrm{C}$ in zones $\mathrm{Q} 3$ and Q2. During the year of the fire, in zones Q2, Q3 and P, temperatures were higher than the mean. However, during the subsequent 3 years of study, values were very similar to the mean. Consequently, variations in temperature after burning do not explain the possible changes in vegetation during post-fire regeneration. 


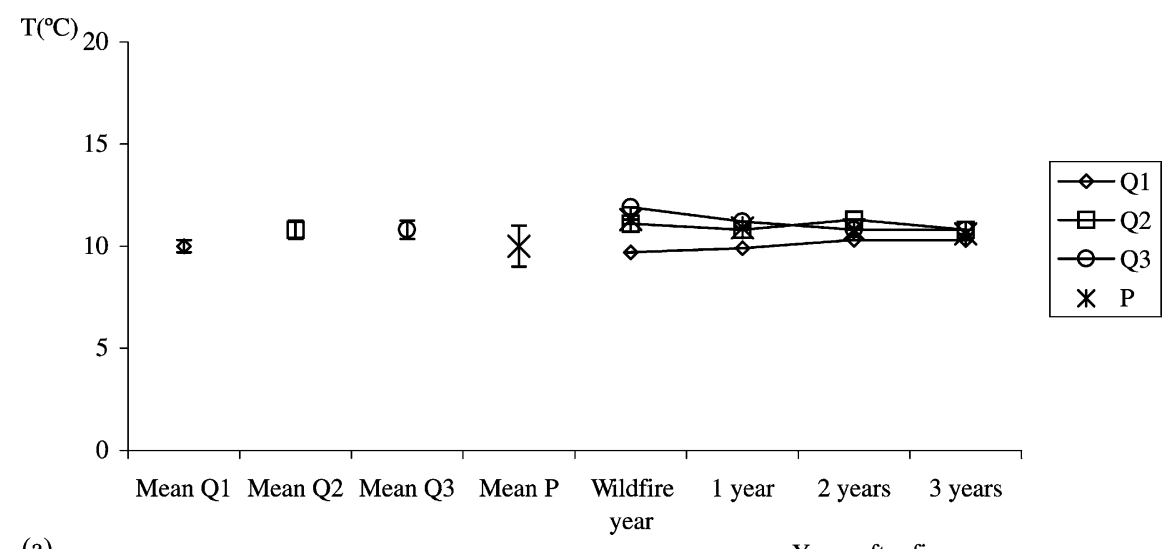

(a)

Years after fire

(b)

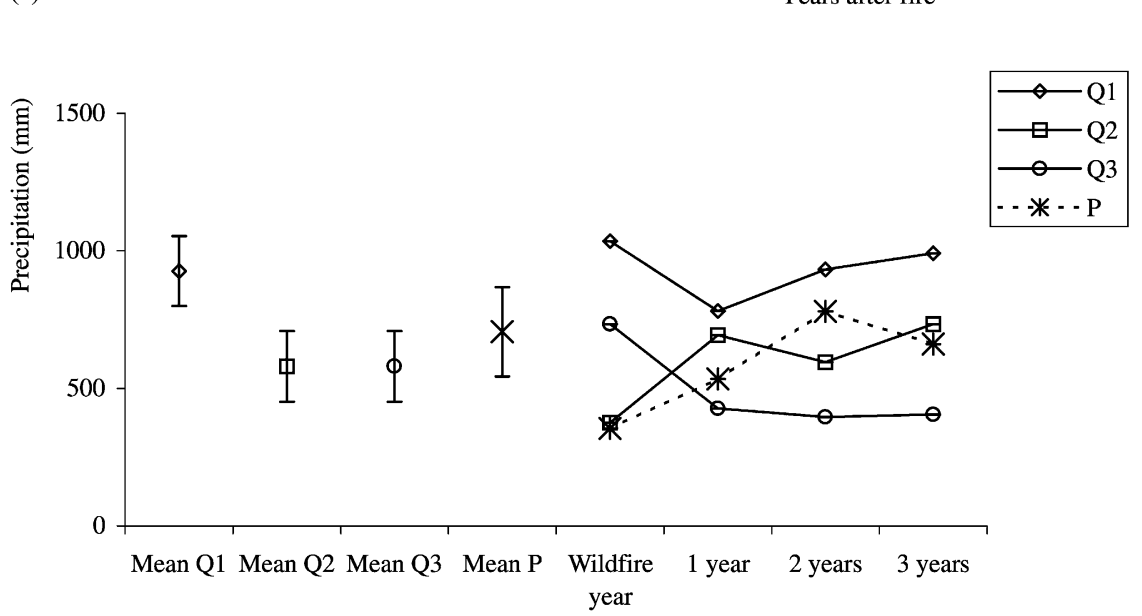

Years after fire

Fig. 1. Precipitation data from the meteorological stations that characterise the study areas (Q1, Q2, Q3, and Pinus stand). Mean Q1, Mean Q2, Mean Q3 and Mean P: long term mean values (20 years) and standard deviation. Wildfire year: precipitation in the year of the fire. 1, 2, 3 years: precipitation during the years after wildfire.

Mean annual precipitations in each zone are slightly different (Fig. 1b). Zone Q1 can be defined as the wettest (927 mm), and zones Q2 and Q3 as the driest $(580 \mathrm{~mm})$; intermediate conditions occur in the plots located at Pinar. In the years during which the fires occurred (Q1: 1985; Q2: 1986; Q3: 1989 and P: $1998)$, lower precipitation values were recorded in zones Q2 and P. In other words, they can be defined as dry years. This condition and higher temperatures are the two factors with the greatest influence on the presence of the fire. In the 3 years following the fires, there were only notably dry years in zone Q3. Consequently, in zone Q3 regeneration took place under drought conditions.
Zone Q1 has the highest precipitation, in terms of mean values $(927 \mathrm{~mm})$, both in the year in which the fire occurred and in the following years. The other zones, Q2 and P, showed similar variations around the mean. Consequently, variations in precipitation do occur between zones, but this possibly owes more to spatial and altitudinal variations between the study zones than differences in the years in which the fires occurred. The only zone where this parameter may influence regeneration is zone Q3, which was dry during the years of post-fire regeneration.

Bare soil is clearly dominant in both communities during the first year after the fire (Fig. 2), with higher values in the pine wood $(99.7 \%)$ than in the oak forest 

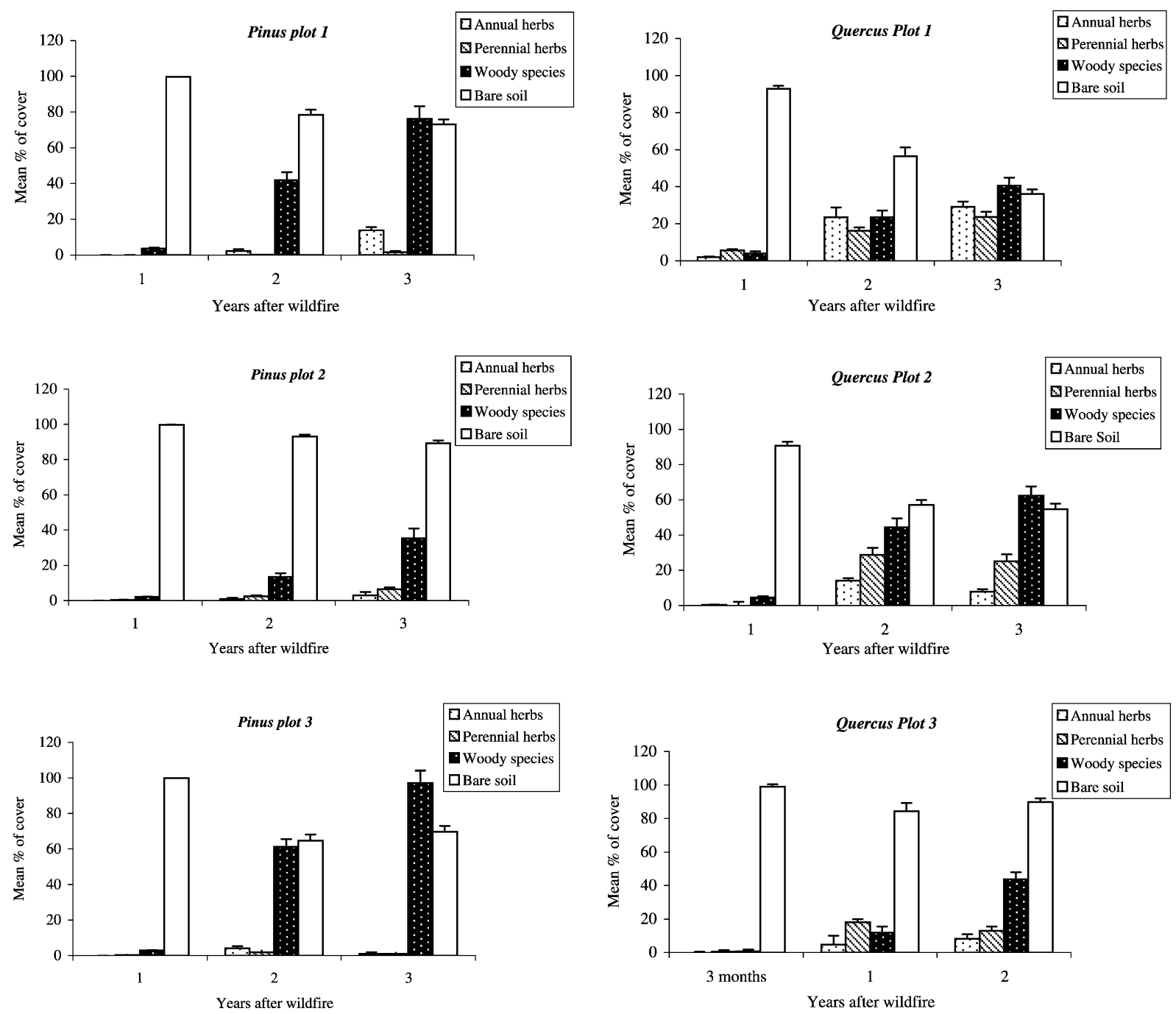

Fig. 2. Mean cover of the life forms (annuals, perennial herbs and woody species) and bare soil in the Quercus communities and Pinus communities. $3 \mathrm{~m}$ : months after fire; 1, 2, 3: years after fire.

$(89.32 \%)$. This allows significant differences to be recognised between the two communities (Table 1). As time passes the percentage of bare soil decreases, with no significant differences between the two communities in the second or third year.

This decrease in the percentage of bare soil is due to the increase in vegetation cover, mainly of woody species. After the fire the cover of woody species increases over time in both the pine and oak communities. However, this increase in cover is only significant between the first and third years in the pine stand communities (Table 1). The variability in cover values within each study area means that no differences can be detected between communities. It is possible to detect differences between the two communities over time by comparing them via the percentage of woody species. That is how significant differences over time between the two communities are evident, since the percentage of woody species is significantly higher in the pine wood after 1 year and 2 years than in the oak wood (Table 2). However, although the percentage of woody species continues to be higher in the pine stand 
Table 1

Tables of two factor repeated measure analysis of variance to compare mean cover values of annual herbs, perennial herbs, woody species and bare soil ${ }^{\mathrm{a}}$

\begin{tabular}{|c|c|c|c|c|c|c|c|c|c|c|c|c|c|}
\hline \multirow[t]{2}{*}{ Source } & \multirow[t]{2}{*}{ d.f. } & \multicolumn{3}{|c|}{ Annual herbs } & \multicolumn{3}{|c|}{ Perennial herbs } & \multicolumn{3}{|c|}{ Woody species } & \multicolumn{3}{|l|}{ Bare soil } \\
\hline & & Mean squ. & $F$-test & $P$-value & Mean squ. & $F$-test & $P$-value & Mean squ. & $F$-test & $P$-value & Mean squ. & $F$-test & $P$-value \\
\hline Site (A) & 1 & 363.529 & 5.376 & 0.1032 & 1030.225 & 40.73 & 0.0078 & 185.646 & 0.233 & 0.6625 & 1530.334 & 10.594 & 0.0473 \\
\hline Subjects within groups & 3 & 67.622 & & & 25.294 & & & 797.854 & & & 144.459 & & \\
\hline Repeated measure (B) & 2 & 156.824 & 5.6 & 0.0424 & 88.41 & 12.828 & 0.0068 & 4370.96 & 21.991 & 0.0017 & 1467.633 & 24.351 & 0.0013 \\
\hline $\mathrm{AB}$ & 2 & 74.973 & 2.677 & 0.1475 & 66.097 & 9.59 & 0.0135 & 117.813 & 0.593 & 0.5822 & 172.207 & 2.857 & 0.1344 \\
\hline $\mathrm{B} \times$ subjects within groups & 6 & 28.003 & & & 6.892 & & & 198.759 & & & 60.269 & & \\
\hline
\end{tabular}

${ }^{\mathrm{a}}$ We used the cover values from 1 to 3 years in the sites P1, P2, P3 and Q1, Q2, in the site Q3 we used 1 and 2 years after wildfire. 
Table 2

Tables of two factor repeated measure analysis of variance to compare percentage of life forms: annual herbs, perennial herbs and woody species $^{\mathrm{a}}$

\begin{tabular}{|c|c|c|c|c|c|c|c|c|c|c|}
\hline \multirow[t]{2}{*}{ Source } & \multirow[t]{2}{*}{ d.f. } & \multicolumn{3}{|c|}{ Annual herbs } & \multicolumn{3}{|c|}{ Perennial herbs } & \multicolumn{3}{|c|}{ Woody species } \\
\hline & & Mean squ. & $F$-test & $P$-value & Mean squ. & $F$-test & $P$-value & Mean squ. & $F$-test & $P$-value \\
\hline Site (A) & 1 & 732.736 & 3.682 & 0.1508 & 3530.641 & 21.764 & 0.0186 & 7485.696 & 54.572 & 0.0051 \\
\hline Subjects within groups & 3 & 199.031 & & & 162.221 & & & 137.171 & & \\
\hline Repeated measure (B) & 2 & 149.766 & 10.027 & 0.0122 & 371.762 & 14 & 0.0055 & 61.701 & 0.898 & 0.4558 \\
\hline $\mathrm{AB}$ & 2 & 43.069 & 2.884 & 0.1326 & 327.161 & 12.32 & 0.0075 & 233.369 & 3.397 & 0.1031 \\
\hline $\mathrm{B} \times$ subjects within groups & 6 & 14.936 & & & 26.554 & & & 68.697 & & \\
\hline
\end{tabular}

\footnotetext{
${ }^{\mathrm{a}}$ We used the percentage of life forms from 1 to 3 years in the sites P1, P2, P3 and Q1, Q2, in the site Q3 we used 1 and 2 years after
} wildfire.

in the third year, the differences are no longer significant. In addition to presenting differences in the percentages of woody species, qualitative differences can also be recognised in the dominant woody species in both communities. In the pine stand (Table 3 ) the presence of $P$. pinaster, Halimium alyssoides and Chamaespartium tridentatum with relatively high values are of interest. The first two are obligate seeders in this study areas (personal observation) whilst the third is a typical resprouter. In the oak community (Table 4) there is a large number of woody species with $Q$. pyrenaica, Erica australis and $C$. tridentatum dominating; all of which are typical resprouters. The following species appear with lower cover values: $H$. alyssoides and Cistus laurifolius, both seeders. The increase in cover values through time is not significant (Table 1).

Herbaceous perennials are practically non-existent in the pine communities throughout the 3-year study period (Fig. 2) whilst they have relatively high cover values in the oak communities in the second and third study years. This shows that there are significant differences $(P<0.05)$ between all the study years evident from comparing the cover values of the herbaceous perennials in the oak community with those in the pine stand (Table 1). However, increases in the cover of herbaceous perennials through time are not significant $(P>0.05)$ in either of the communities (Table 1). The same results are evident when the percentages of herbaceous perennials are compared (Table 2). Among the herbaceous perennials present in the pine stand (Table 3), two Compositae Hypochoeris radicata and Hieracium pillosella and a Liliacea Ornithogalum umbellatum stand out. The Gramineae
Avenula marginata subsp. sulcata, Festuca rubra and Luzula lactea and the Leguminoseae Lotus corniculatus have high cover values in the oak communities (Table 4).

The herbaceous annuals tend to have relatively high values during the second and third year after the fire (Fig. 2), particularly in the oak communities. In general, higher cover values are recorded in the oak community than in the pine stand. In spite of there being a larger quantity of herbaceous annuals in the oak community, statistically significant differences between the two communities are only detected (Table 1) during the second year. No significant increase in mean cover values in time can be seen in any of the communities studied (Table 1), since there is a significant variation between the areas studied within each community. These results can be observed by comparing the percentages of herbaceous annuals (Table 2). The Compositae Senecio vulgaris and Andryala integrifolia have the highest cover values in the pine stand (Table 3 ). The Gramineae Aira caryophyllea, the Compositae Arnoseris minima, Logfia minima stand out in the oak community (Table 4).

The structural parameters show that richness (Table 5) is always higher in the oak community with values of close to 40 species in comparison with the 10 appearing in the pine stand. These differences in the richness values are significant during the three study years (Table 6). Richness tends to increase slightly through time with statistically significant differences detected throughout the study period in both communities (Table 6). Similar patterns can be observed in the diversity parameter, with significant differences between the two zones appreciable in all the study 
Table 3

Mean percentage cover and standard error (in branches) of the most abundant species in the plots situated P. pinaster area (P1, P2, P3) in the years 1, 2, 3 after wildfire ${ }^{\mathrm{a}}$

\begin{tabular}{|c|c|c|c|c|c|c|c|c|c|c|c|c|}
\hline & \multirow{2}{*}{$\begin{array}{l}\text { Life } \\
\text { forms }\end{array}$} & \multirow{2}{*}{$\begin{array}{l}\text { Biological } \\
\text { traits }\end{array}$} & \multirow{2}{*}{$\begin{array}{l}\text { Reproductive } \\
\text { strategies }\end{array}$} & \multicolumn{9}{|c|}{ Plots in time after wildfire } \\
\hline & & & & P1-1 & P1-2 & P1-3 & P2-1 & P2-2 & $\mathrm{P} 2-3$ & P3-1 & P3-2 & P3-3 \\
\hline$P$. pinaster & $\mathrm{Ph}$ & $\mathrm{W}$ & S & $1.6(0.15)$ & $6.9(1.22)$ & $12.65(1.50)$ & $0.9(0.06)$ & $4.45(0.84)$ & $8.3(6.75)$ & $1.0(0.00)$ & $15.15(1.84)$ & 20.5 \\
\hline H. alyssoides & $\mathrm{C}$ & W & $\mathrm{S}$ & $1.4(0.17)$ & $6.0(2.22)$ & $13.25(4.85)$ & $0.7(0.10)$ & $2.45(0.90)$ & $8.05(2.21)$ & $0.85(0.20)$ & $28.5(4.47)$ & $49.0(6.16)$ \\
\hline C. tridentatum & $\mathrm{C}$ & $\mathrm{W}$ & $\mathrm{S}$ and $\mathrm{R}$ & $0.8(0.19)$ & $25.35(4.16)$ & $43.75(5.33)$ & $0.55(0.20)$ & $6.2(1.34)$ & $14.05(2.78)$ & $0.90(0.10)$ & $13.75(1.61)$ & 18.85 \\
\hline E. australis & $\mathrm{C}$ & W & $\mathrm{S}$ and $\mathrm{R}$ & $0.1(0.11)$ & $3.5(1.62)$ & $6.55(2.61)$ & & $0.35(0.26)$ & $4.5(1.22)$ & & $3.75(1.39)$ & 8.5 \\
\hline S. vulgaris & $\mathrm{T}$ & A & S & & $1.75(0.69)$ & $12.5(1.23)$ & & $0.9(0.55)$ & $5.45(0.79)$ & & $4.15(1.14)$ & $0.75(0.54)$ \\
\hline Andryla integrifolia & $\mathrm{T}$ & A & S & & $0.25(0.25)$ & $0.25(0.25)$ & & & $0.20(0.15)$ & & & \\
\hline A. caryophyllea & $\mathrm{T}$ & A & S & & & & & & $0.6(0.34)$ & & & \\
\hline H. radicata & $\mathrm{He}$ & $P$ & $\mathrm{~S}$ and $\mathrm{R}$ & & $0.1(0.1)$ & $0.8(0.38)$ & & $0.9(0.5)$ & $0.3(0.25)$ & & $0.45(0.28)$ & \\
\hline Hieracium pilosella & $\mathrm{He}$ & $P$ & $\mathrm{~S}$ and $\mathrm{R}$ & & $0.05(0.05)$ & $0.7(0.36)$ & & $0.1(0.1)$ & $0.3(0.18)$ & & & \\
\hline O. umbellatum & $\mathrm{G}$ & $\mathrm{P}$ & $\mathrm{S}$ and $\mathrm{R}$ & & & & $0.4(0.15)$ & $1.4(0.50)$ & $2.5(1.49)$ & $0.35(0.11)$ & $1.3(0.61)$ & $1.0(0.58)$ \\
\hline
\end{tabular}

${ }^{\mathrm{a}}$ Biological traits—A, annual herbaceous; P, perennial herbaceous; W, woody species. Life forms-T, therophyte; He, hemicryptophyte; $\mathrm{C}$, chamaephyte; Ph, phanerophyte Reproductive strategies-S, seeders; R, resprouters. 
Table 4

Mean percentage cover and standard error (in branches) of the most important species in the plots situated in Q. pyrenaica communities (Q1, Q2, Q3) in the years 1, 2, 3 after wildfire (3m: 3 months) ${ }^{\text {a }}$

\begin{tabular}{|c|c|c|c|c|c|c|c|c|c|c|c|c|}
\hline & \multirow{2}{*}{$\begin{array}{l}\text { Life } \\
\text { forms }\end{array}$} & \multirow{2}{*}{$\begin{array}{l}\text { Reproductive } \\
\text { strategies }\end{array}$} & \multirow{2}{*}{$\begin{array}{l}\text { Biological } \\
\text { traits }\end{array}$} & \multicolumn{9}{|c|}{ Plots in time after wildfire } \\
\hline & & & & Q1-1 & Q1-2 & Q1-3 & Q2-1 & Q2-2 & Q2-3 & Q3-3m & Q3-1 & Q3-2 \\
\hline$Q$. pyrenaica & $\mathrm{Ph}$ & $\mathrm{S}$ and $\mathrm{R}$ & $\mathrm{W}$ & $3.64(1.12)$ & $19(3.42)$ & $29.24(4.32)$ & $2.0(0.83)$ & $20.88(5.96)$ & $23.4(6.65)$ & $1.75(0.35)$ & $1.56(0.3)$ & $7.08(1.42)$ \\
\hline C. tridentatum & $\mathrm{C}$ & $\mathrm{S}$ and $\mathrm{R}$ & W & $0.12(0.08)$ & $0.6(0.22)$ & $1.24(0.62)$ & $1.20(0.29)$ & $4.52(1.10)$ & $5.52(1.49)$ & $0.16(0.02)$ & $6.12(1.22)$ & $7.6(1.52)$ \\
\hline E. australis & $\mathrm{C}$ & $\mathrm{S}$ and $\mathrm{R}$ & $\mathrm{W}$ & $0.16(0.09)$ & $2.8(0.91)$ & $5.84(1.58)$ & $0.6(0.21)$ & $13.32(2.09)$ & $22.88(3.41)$ & & $1.36(0.27)$ & $5.4(1.08)$ \\
\hline H. alyssoides & $\mathrm{C}$ & $\mathrm{S}$ & $\mathrm{W}$ & $0.08(0.05)$ & $1.0(0.31)$ & $4.0(1.36)$ & & & & & $7.16(1.43)$ & $15.24(3.05)$ \\
\hline A. caryophyllea & $\mathrm{T}$ & $\mathrm{S}$ & A & $1.12(0.32)$ & $17(4.74)$ & $16.6(2.26)$ & $0.08(0.06)$ & $2.2(0.57)$ & $3.6(0.67)$ & & $0.88(0.18)$ & $2.6(0.52)$ \\
\hline A. minima & $\mathrm{T}$ & S & A & $0.36(0.09)$ & $1.6(0.44)$ & $2.0(0.31)$ & $0.08(0.06)$ & $1.04(0.56)$ & $0.56(0.12)$ & & & $1.16(0.23)$ \\
\hline L. minima & $\mathrm{T}$ & $S$ & A & $0.08(0.05)$ & $0.4(0.11)$ & $2.08(0.42)$ & & $5.28(0.78)$ & $0.48(0.1)$ & & $0.04(0.008)$ & $0.76(0.15)$ \\
\hline Arenaria montana & $\mathrm{He}$ & $\mathrm{S}$ and $\mathrm{R}$ & $\mathrm{P}$ & $0.64(0.13)$ & $1.3(0.34)$ & $2.48(0.6)$ & $2.08(0.63)$ & $4.92(1.06)$ & $3.88(0.73)$ & & $0.32(0.06)$ & $0.88(0.18)$ \\
\hline A. marginata & $\mathrm{He}$ & $\mathrm{S}$ and $\mathrm{R}$ & $\mathrm{P}$ & $0.32(0.21)$ & $0.7(0.32)$ & $2.44(1.02)$ & & $0.04(0.04)$ & $0.04(0.04)$ & $0.08(0.01)$ & $0.84(0.16)$ & $5.12(1.02)$ \\
\hline Deschapsia flexuosa & $\mathrm{He}$ & $\mathrm{S}$ and $\mathrm{R}$ & $\mathrm{P}$ & & & $1.28(0.52)$ & $0.2(0.13)$ & $0.84(0.61)$ & $0.2(0.2)$ & & $1.28(0.26)$ & \\
\hline F. rubra & $\mathrm{He}$ & $\mathrm{S}$ and $\mathrm{R}$ & $\mathrm{P}$ & $1.56(0.66)$ & & $3.36(1.41)$ & $0.64(0.28)$ & $3.28(0.93)$ & $3.92(1.08)$ & & $1.24(0.25)$ & $1.72(0.34)$ \\
\hline L. corniculatus & $\mathrm{He}$ & $\mathrm{S}$ and $\mathrm{R}$ & $\mathrm{P}$ & $0.08(0.05)$ & $0.3(0.09)$ & $1.16(0.34)$ & $5.08(0.74)$ & & $0.04(0.04)$ & & $1.48(0.29)$ & $1.32(0.26)$ \\
\hline L. lactea & $\mathrm{He}$ & $\mathrm{S}$ and $\mathrm{R}$ & $\mathrm{P}$ & $1.32(0.45)$ & $4.3(1.48)$ & $4.92(1.92)$ & & $8.84(1.09)$ & $5.68(1.15)$ & & $4.0(0.80)$ & $3.28(0.66)$ \\
\hline
\end{tabular}

${ }^{\text {a }}$ Biological traits-A, annual herbaceous; P, perennial herbaceous; W, woody species. Life forms-T, therophyte; He, hemicryptophyte; C, chamaephyte; Ph, phanerophyte. Reproductive strategies-S, seeders; $R$, resprouters. 
Table 5

Values over time of species richness, evenness and diversity in the three plots of $P$. pinaster community $(\mathrm{P} 1, \mathrm{P} 2, \mathrm{P} 3)$ and in the three plots of Q. pyrenaica communities (Q1, Q2, Q3)

\begin{tabular}{lrrrrrr}
\hline & $\mathrm{P} 1$ & $\mathrm{P} 2$ & $\mathrm{P} 3$ & $\mathrm{Q} 1$ & $\mathrm{Q} 2$ & $\mathrm{Q} 3$ \\
\hline Richness & & & & & & \\
1 Year & 4 & 4 & 5 & 23 & 20 & 33 \\
2 Years & 10 & 8 & 9 & 33 & 30 & 29 \\
3 Years & 10 & 12 & 9 & 33 & 39 & \\
Evenness & & & & & & \\
1 Year & 0.68 & 0.90 & 0.90 & 0.74 & 0.74 & 0.80 \\
2 Years & 0.57 & 0.79 & 0.70 & 0.64 & 0.73 & 0.80 \\
3 Years & 0.66 & 0.75 & 0.60 & 0.73 & 0.65 & \\
$H^{\prime}$ gamma & & & & & & \\
1 Year & 1.36 & 1.79 & 2.00 & 3.36 & 3.18 & 3.80 \\
2 Years & 1.88 & 2.36 & 2.20 & 3.25 & 3.77 & 3.80 \\
3 Years & 2.19 & 2.68 & 1.90 & 3.68 & 3.46 & \\
\hline
\end{tabular}

years (Table 6), as values are much greater in the oak community than in the pine stand. However, no significant increases are observed for each community time (Table 6). There are no clear variations in the evenness values through time, with no significant differences within each community through time or between communities during the 3-year study (Table 6).

Finally, analysis of principal components (Fig. 3) show that axis I (explained variance 57\%) allows differentiation of the samples in the oak community (positive part of the axis) from those in the pine stand (negative part of the same axis). The oak community is characterised by a high number of herbaceous annuals, perennials and woody species as well as by high cover values for herbaceous perennials and annuals. Axis II (explained variance $25 \%$ ) allows discrimination of regeneration time since the fire. The samples from the first few years with high percentage of bare soil have negative values and the samples recorded in the last few years, characterised by the high cover values for woody species, are in the positive part.

\section{Discussion}

Effects of fire on vegetation are usually the most obvious impacts of burning. Fire affects natural ecosystems by consuming plants, altering successional patterns, and changing vegetative resources such as timber, forage, and wildlife habitats (DeBano et al., 1998). In post-fire succession studies many factors have to be taken into account, such as the characteristics of the vegetation before the fire, the season when it occurs, the intensity of the fire, the concentration of ash, nutrients added to the soil, rain, air and soil temperature, and animal populations associated with the habitat. These parameters as a whole determine the response of the vegetation. In wildfires, however, it is very difficult to analyse many of these parameters: only the season is easily recorded.

The main effects associated with the season when the fire occurs are determined by the characteristics of the fuel and thus the intensity the fire can reach. Spring fires typically, due to the higher levels of moisture in the fuel and in the atmosphere, reach lower intensities than autumn fires, and have a limited impact on resprouting or germination (Ohmann and Grigal, 1981; Calvo et al., 1992; Domínguez et al., 2002). In the case of fires at the end of summer or beginning of autumn, fuels are drier and therefore burn more easily, resulting in very high intensities which, in some cases, have a negative effect on resprouting in comparison with germination (Allen and Partridge, 1988;

Table 6

Tables of two repeated measure analysis of variance to compare richness, evenness and diversity values in the sites ${ }^{\mathrm{a}}$

\begin{tabular}{|c|c|c|c|c|c|c|c|c|c|c|}
\hline \multirow[t]{2}{*}{ Source } & \multirow[t]{2}{*}{ d.f. } & \multicolumn{3}{|l|}{ Richness } & \multicolumn{3}{|l|}{ Evenness } & \multicolumn{3}{|l|}{ Diversity } \\
\hline & & Mean squ. & $F$-test & $P$-value & Mean squ. & $F$-test & $P$-value & Mean squ. & $F$-test & $P$-value \\
\hline Site (A) & 1 & 1707.38 & 23049.6 & 0.0001 & 0.002 & 0.119 & 0.7526 & 7.157 & 65.21 & 0.004 \\
\hline Subjects within groups & 3 & 0.074 & & & 0.047 & & & 0.329 & & \\
\hline Repeated measure (B) & 2 & 117.8 & 20.721 & 0.002 & 0.04 & 4.276 & 0.0701 & 0.551 & 3.376 & 0.1042 \\
\hline $\mathrm{AB}$ & 2 & 22.14 & 3.895 & 0.0824 & 0.008 & 0.806 & 0.4899 & 0.038 & 0.236 & 0.7969 \\
\hline $\mathrm{B} \times$ subjects within groups & 6 & 5.68 & & & 0.028 & & & 0.49 & & \\
\hline
\end{tabular}

\footnotetext{
${ }^{\text {a }}$ We used the values from 1 to 3 years in the sites P1, P2, P3 and Q1, Q2, in the site Q3 we used 1 and 2 years after wildfire.
} 

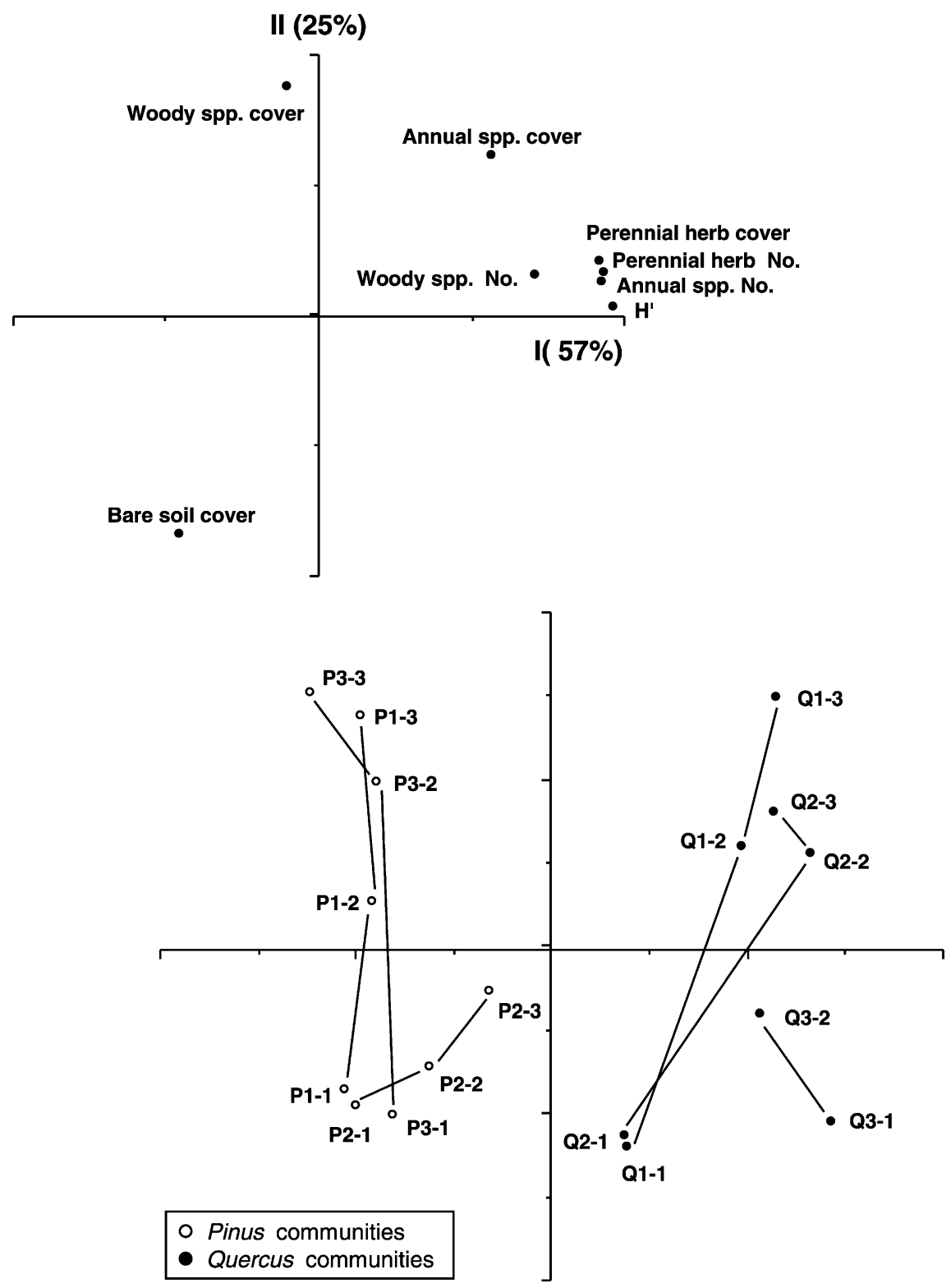

Fig. 3. Location of variables and samples in the plane defined by the first two axes of the correspondence analysis. (The first number after letters representing Pinus or Quercus communities indicates each zone, and the second number indicates years after fire.)

Calvo et al., 1992; Moreno and Oechel, 1994; Canadell and López-Soria, 1998; Domínguez et al., 2002). No marked differences relating to the season of the fire are observed in the two types of community studied, as both were burned at the end of summer. However, there may be differences between the two communities in the intensity reached by the fires, with possibly greater intensities in the pine stand than in the oak wood. The dominant species, $P$. pinaster, is characterised by a high resin content, which is one of the factors that probably favours ignition (Van Wagner, 1983; Elvira and Hernándo, 1989) and increases the amount of energy released when the foliage burns. P. pinaster foliage has a high surface 
area to volume ratio and this is other factor that can favour ignition. In contrast, the dominant arboreal species in the oak wood does not have this type of substance, which increases inflammability. This means that the intensity reached in both types of community are likely to be different. This is confirmed by personal observation of the state of the vegetation after the fire. There was more destruction of vegetation in the pine stand than in the oak wood.

These differences in the intensity reached by the fire can influence the speed and the way in which a postfire recovery process starts (Gill and Groves, 1981). However, in addition to bearing these parameters in mind, the type of vegetation affected must be considered particularly as strategies used for recovery. Post-fire regeneration types were from species regenerating only from stored seeds (obligate seeder species) to species regenerating by resprouting (obligate resprouters) and species that are capable of both (resprouters/seeders) (Keeley and Zedler, 1978; Keeley, 1992; Bond and Van Wilgen, 1996). In the case of seeder species, all individuals die as a result of fire, and recruitment is only possible from seeds that survive. The size of the seed pool may then determine the likelihood of new establishments. A higher investment of resources in sexually related regeneration structures may then be advantageous to survive the disturbance (Cruz and Moreno, 2001). In the other case, resprouter species, most individuals survive the fire. Resprouting requires carbon reserves that, subsequent to the disturbance, will be mobilised to develop the new tissue (Miyanishi and Kellman, 1986). In both types of community studied, relationships relating to the success of the species, which recover and differences in regeneration mechanism are evident. So in the pine community, that most affected by the fire, species using germination as a recovery mechanism dominate. Amongst this group, $P$. pinaster is notable as the seeds are contained in the cone and liberated at relatively high temperatures such as those induced by fire (Trabaud, 1995). Similarly, $H$. alyssoides, obligated seeders in this study areas (Calvo et al., 2002) germinates from a persistent soil seed bank which is stimulated by a thermal increase, as occurs with other Cistaceae after a fire (Alonso et al., 1992; Thanos et al., 1992; Valbuena et al., 1992; Trabaud and Renard, 1999). These results support the findings of previous authors (Moreno and Oechel,
1994; Canadell and López-Soria, 1998), in that the areas where the fire reached the greatest intensity seeders seem to benefit.

In the oak communities, where a lower temperature was possibly reached during the fire, the most important species are woody taxa which use vegetative resprouting as a regeneration mechanism, including $Q$. pyrenaica, E. australis and $C$. tridentatum. The buds of $E$. australis, a resprouting species typical of these communities, are found in the lignotuber (Canadell and López-Soria, 1998). The presence of a lignotuber gives this species a great regenerative advantage after a fire (Moreno et al., 1999). The potential capacity for storing starch is much greater in species of the genus Erica than in other resprouters (Bell and Ojeda, 1999). However, in addition to resprouting vigorously, it is also capable of germinating from the seeds stored in the soil seed bank. Several authors have studied the germination capacity of various Ericaceae after perturbations such as fire (Ojeda et al., 1996; Obeso and Vera, 1996; Calvo et al., 1998a,b). The main difference between germination and resprouting is that the first mechanism requires more time to appear. $Q$. pyrenaica also typically resprouts from the shoots on the rhizome or the stem of the subterranean roots (Calvo et al., 1991; LuisCalabuig et al., 2000). In this species germination capacity in the field is low. In C. tridentatum resprouting occurs from the bank of shoots situated in the root (Casal, 1987; Tárrega et al., 1992). This species undergoes similar changes to those described by many authors for other resprouting species (Le Maitre and Midgley, 1992): in a process of progressive ageing of the aerial biomass only the outer edge of each branch remains green. Therefore, recurring perturbations favour rejuvenation.

In addition to differences between the two communities in terms of the type of woody vegetation present, there are differences in the abundance and specific richness of the herbaceous species appearing after the fire. One year after the fire herbaceous perennials are clearly dominant in the oak wood communities. This idea of a greater quantity of herbs in the areas less affected by the fires has been recorded previously by Clark (1988). Immediately following fire these herbaceous perennials may find conditions favourable for establishment: there is no competition with woody species for light and they have superficial roots which allow them to take advantage quickly of the nutrients 
which the ash contributes to the soil. All these factors may facilitate initial colonisation of the ecosystem. In contrast, in the pine stand communities the quantity of herbaceous perennials is much smaller during the study years. This may be because the fire destroys the seeds in the first few centimetres of soil or because of the clear predominance of woody species from the second year after the fire, with cover values close to $50 \%$, out-competing herbaceous species. This is the period when the greatest explosion of herbaceous species is generally observed. Alternatively, it may also be due to the presence of allelopathic substances which could inhibit herbaceous species. Various studies have demonstrated that $P$. pinaster produces oleoresins like terpenes and fatty acids (DesprezLoistau and Wagner, 1997) which could act as inhibitors of other species in those communities. It is of note that the most representative species among the herbaceous perennials was $O$. umbellatum, which appeared throughout the study period in all the burned plots. The stimulation of flowering by fire is a very common phenomenon in monocotyledons, especially in the Mediterranean areas (Le Maitre and Midgley, 1992). This is typical in the Liliacea, which bud and flower from bulbs or subterranean rhizomes.

In general, the herbaceous annuals in both communities are present at low cover values. Differences can be observed between the two communities, with more herbaceous annuals in the oak wood than in the pine stand. The low cover values of annual herbs do not correlate with those found in other Mediterranean communities 1 year after a fire (Arianoutsou and Margaris, 1981; Keeley, 1981; Casal et al., 1990; Kazanis and Arianoutsou, 1996).

One possible hypothesis to explain differences in the quantity of herbaceous taxa in the pine and oak communities involves analysing variations in precipitation in the years following the fire. However, this hypothesis fails when the communities are compared, primarily due to the quantity of herbaceous cover which appeared in zone Q3. This zone experienced drought conditions in the years following the fire, but had a greater quantity of herbaceous taxa, both annuals and perennials, than any of the pine plots.

Therefore, a more credible hypothesis may be based on the quantity of herbs present in the soil seed bank. Studies on the composition of the soil seed bank in the pine community (Valbuena et al., 2002) demonstrate that the seed bank is very poor and, moreover, that there are virtually no herbs. Thus, in this case, it is possible that the richness of the soil seed bank, rather than climatic factors, resulted in differences in regeneration patterns.

On the contrary, a comparison of regeneration in the different oak zones suggests that the amount of precipitation has possible effects on regeneration, since the greatest quantity of vegetation appeared in plot Q1, where there was most precipitation.

The structural parameters show a clear difference between communities. Richness and $H^{\prime}$ were higher in the Quercus communities than in the Pinus stand. Each community has a particular species composition, which allows some distinctions to be made between them. Both types of communities showed a similar post-fire variation pattern, in general the tendency is for the richness values to increase in time.

All the previously mentioned differences are shown by the multifactorial analysis, in which the studied communities are clearly differentiated, although the common tendencies in recovery over time are observed in terms of the second axis of the analysis.

\section{Conclusion}

It can be concluded that the Quercus communities recover more rapidly than the Pinus communities. This is associated by the life forms that appeared during the first years after fire. Woody species (mainly seeders) dominate from the first instance in the Pinus communities, where the presence of herbs is very low. There is a clear dominance of herbaceous species and relatively high values for resprouters in Quercus communities in the first 2 years after the fire. Similarly, this greater recovery capacity is shown by higher specific richness values in oak woods than in the pine stands from the first.

\section{References}

Allen, R.B., Partridge, T.R., 1988. Effects of spring and autumn fires on the composition of Chionochloa rigida Tussock Grassland, New Zealand. Vegetatio 76, 37-44.

Alonso, I., Tárrega, R., Luis, E., 1992. First phases of regeneration of Cistus laurifolius and Cistus ladanifer after burning and cutting in experimental plots. Int. J. Wildland Fire 2, 7-14. 
Arianoutsou, M., Margaris, N.S., 1981. Early stages of regeneration after fire in a phrygranic ecosystem (East Mediterranean). I. Regeneration by seed germination. Biologie Ecologie Méditerranéenne 8, 119-128.

Baskin, J.M., Baskin, C.C., 1998. Seed, Ecology, Biogeography and Evolution of Dormancy and Germination. Academic Press, San Diego.

Bell, T.L., Ojeda, F., 1999. Underground starch storage in Erica species of the Cape Floristic Region differences between seeders and resprouters. New Phytol. 144, 143-152.

Bond W.J., Van Wilgen, B.W., 1996. Fire and Plants. Chapman \& Hall, London.

Calvo, L., Tárrega, R., Luis, E., 1991. Regeneration in Quercus pyrenaica ecosystems after surface fires. Int. J. Widland Fire 1, 205-210.

Calvo, L., Tárrega, R., Luis, E., Marcos, E., 1992. Differences in vegetal regeneration by effects of spring and summer fires in Quercus pyrenaica forests. In: Teller, A., Mathy, P., Jeffers, J.N.R. (Eds.), Responses of Forest Ecosystems to Environmental Changes. Elsevier, Amsterdam, pp. 855-857.

Calvo, L., Tárrega, R., Luis, E., 1998a. Space-time distribution patterns of Erica australis L. subsp. aragonensis (Willk) after experimental burning, cutting, and ploughing. Plant Ecol. 137, $1-12$.

Calvo, L., Tárrega, R., Luis, E., 1998b. Twelve years of vegetation changes after fire in an Erica australis community. In: Trabaud, L. (Ed.), Fire Management and Landscape Ecology. International Association of Wildland Fire. Fairfield, Washington, pp. 123-136.

Calvo, L., Tárrega, R., Luis, E., 1999. Post-fire succession in two Quercus pyrenaica communities with different disturbance histories. Ann. For. Sci. 56, 441-447.

Calvo, L., Tárrega, R., Luis, E., 2002. The dynamics of mediterranean shrubs species over 12 years following perturbations. Plant Ecology 160, 25-42.

Canadell, J., López-Soria, L., 1998. Lignotuber reserves support regrowth following clipping of two Mediterranean shrubs. Funct. Ecol. 12, 31-38.

Casal, M., 1987. Post-fire dynamics of shrublands dominated by Papilionacea plants. Influence of fire on the stability of Mediterranean forest ecosystems. Ecologia Mediterranea XIII (4), 87-98.

Casal, M., Basanta, M., González, F., Montero, R., Pereiras, J., Puentes, A., 1990. Post-fire dynamics in experimental plots of shrubland ecosystems in Galicia (NW Spain). In: Goldammer, J.G., Jenkins, M.J. (Eds.), Fire in Ecosystem Dynamics. Mediterranean and Northern Perspectives. SPB Academic Publishing, Hague, pp. 33-42.

Clark, S.S., 1988. Effects of hazard-reduction burning on population of understorey plant species on Hawkesbury sandstone. Aust. J. Ecol. 13, 473-484.

Cochran, W.C., 1941. The distribution of the largest of a set of estimated variances as a fraction of their total. Ann. Eugen. (Land) 11, 47-61.

Cruz, A., Moreno, J.M., 2001. No allocation trade-offs between flowering and sprouting in the lignotuberous, Mediterranean shrub Erica australis. Acta Oecol. 22, 1-7.
David, H.A., Hartley, M.O., Pearson, E.S., 1954. The distribution of the ratio in a single normal sample of range to standard deviation. Biometrika 41, 482-493.

DeBano, F.L., Neary, D.G., Ffolliott, P.F., 1998. Fire's Effects on Ecosystems. Wiley, New York.

Desprez-Loistau, M.L., Wagner, K., 1997. Components of maritime pine susceptibility to twisting rust-a path coefficient analysis. Eur. J. Plant Pathol. 103, 653-665.

Domínguez, L., Calvo, L., Luis, E., 2002. Impact of wildfire season on regeneration of Quercus pyrenaica forest and Pinus sp. Stand. J. Mediterr. Ecol. 3, 47-54.

Elvira, L.M., Hernándo, C., 1989. Inflamabilidad y energía de las especies del sotobosque (Inflamability and energy of understory species). Monograph INIA. Madrid (in Spanish).

Gill, A.M., Groves, R.H., 1981. Fire regimes in heathlands and their plant-ecological effects. In: Specht, R.L. (Ed.), Ecosystems of the World 9B. Heathlands and Related Shrublands, Analytical Studies. Elsevier, Amsterdam, pp. 61-84.

Hill, M.O., 1974. Correspondence analysis: a neglected multivariate method. Appl. Stat. 23, 340-354.

Junta de Castilla y León, 1987. Mapa de suelos de Castilla y León (Soils Map in Castilla y León). Junta de Castilla y León. Valladolid (in Spanish).

Kazanis, D., Arianoutsou, M., 1996. Vegetation composition in a post-fire successional gradient of Pinus halepensis forest in Attica, Greece. Int. J. Wildland Fire 6, 83-91.

Keeley, J.E., 1981. Fire regimes and reproductive cycles. In: Mooney, H.A., Bonnicksen, T.M., Christensen, N.L., Lotan, J.E., Reirners, W.A. (Eds.), Fire Regimes and Ecosystem Properties. USDA For. Serv. Gen. Tech. Rep., WO, pp. 231-277.

Keeley, J.E., 1992. Recruitment of seedlings and vegetative sprouts in unburned chaparral. Ecology 73, 1194-1208.

Keeley, J.E., Zedler, P.H., 1978. Reproduction of chaparral shrubs after fire: a comparison of sprouting and seedling strategies. Am. Midl. Nat. 99, 142-161.

Le Maitre, D.C., Midgley, J.J., 1992. Plant reproductive ecology. In: Cowling, R.M. (Ed.), The Ecology of Fynbos. Nutrients, Fire and Diversity. Oxford University Press, Cape Town, pp. 135-174.

Lloret, F., Vilá, M., 1997. Clearing of vegetation in Mediterranean garrigue: response after a wildfire. For. Ecol. Manage. 93, 227-234.

Luis, E., Tárrega, R., 1993. Studies on post-fire regeneration in Quercus pyrenaica ecosystems in León province (NW Spain). In: Trabaud, L., Prodon, R. (Eds.), Fire in Mediterranean Ecosystems. ECSC-EEC-EAEC, Brussels, pp. 69-85.

Luis-Calabuig, E., Tárrega, R., Calvo, L., Marcos, E., Valbuena, L., 2000. History of landscape changes in northwest Spain according to land use and management. In: Trabaud, L. (Ed.), Life and Environment in the Mediterranean. Wit Press, Southampton, pp. 43-86.

Martínez-Sánchez, J., Marín, A., Herranz, J.M., Ferrandis, P., Heras, J., 1995. Effects of high temperatures on germination of Pinus halepensis Mill. and Pinus pinaster Aiton subsp. pinaster seeds in southeast Spain. Vegetatio 116, 69-72.

Miyanishi, K., Kellman, M., 1986. The role of root nutrient reserves in regrowth of two savannah shrubs. Can. J. Bot. 64, 1244-1248. 
Moreno, J.M., Oechel, W.C., 1994. The Role of Fire in Mediterranean-type Ecosystems. Springer, New York.

Moreno, J.M., Cruz, A., Oechel, W.C., 1999. Allometric relationships in two lignotuberous species from Mediterranean-type climate areas of Spain and California. J. Mediterr. Ecol. 1, 49-60.

Naveh, Z., 1975. The evolutionary significance of fire in the Mediterranean region. Vegetatio 29, 199-208.

Obeso, J.R., Vera, M.L., 1996. Resprouting after experimental fire application and seed germination in Erica vagans. Orsis 11, $155-163$.

Ohmann, L.F., Grigal, D.F., 1981. Contrasting vegetation responses following two forest fires in northeastern Minnesota. Am. Midl. Nat. 106 (1), 54-63.

Ojeda, F., Marañon, T., Arroyo, J., 1996. Postfire regeneration of a Mediterranean heathland in southern Spain. Int. J. Wildland Fire 6, 191-198.

Pausas, J., Vallejo, V.R., 1999. The role of fire in European Mediterranean ecosystems. In: Chuvieco, E. (Ed.), Remote Sensing of Large Fires in the European Mediterranean Basin. Springer, New York, pp. 3-16.

Penas, A., Garcia, M.E., Herrero, L., 1995. Series de vegetación (Vegetation series). In: IGME, Diputación de León (Eds.), Atlas del Medio Natural de la Provincia de León. Instituto Tecnológico Geominero de España, Madrid, pp. 29-40.

Pielou, E.C., 1969. The measure of diversity in different types of biological collections. J. Theor. Biol. 13, 131-144.

Rivas, S., 1987. Memoria del mapa de series de vegetación de España (Spanish vegetation map). ICONA, Madrid (in Spanish).

Scheffe, H., 1959. The Analysis of Variance. Wiley, New York.

Shannon, C.E., Weaver, W., 1949. The Mathematical Theory of Communication. University of Illinois Press, Urbana.

Tapias, R., Gil, L., Pardos, J.A., 1998. Los pinares (Pinus pinaster Ait.) de las estribaciones de la Sierra del Teleno (León). La influencia del incendio en su ordenación. (Pinus pinastes forest in the Sierra of Teleno (León)). Fire influence in their management. Montes 52, 115-120 (in Spanish).

Tárrega, R., Calvo, L., Trabaud, L., 1992. Effect of high temperatures on seed germination of two woody Leguminosae. Vegetatio 102, 139-147.

Tárrega, R., Luis Calabuig, E., Alonso, I., 1995. Comparison of the regeneration after burning, cutting and ploughing in a Cistus ladanifer shrubland. Vegetatio 120, 59-67.
Tárrega, R., Luis Calabuig, E., Alonso, I., 1997. Space-time heterogeneity in the recovery after experimental burning and cutting in a Cistus laurifolius shrubland. Plant Ecol. 129, 179-187.

Ter Braak C.J.F., 1991. Update Notes: CANOCO (Version 3.12). Agricultural Mathematics Group, Wageningen, The Netherlands.

Thanos, C.A., Georghiou, K., Kadis, C.C., Pantazi, C., 1992. Cistaceae: a plant family with hard seeds. Israel J. Bot. 41, 251-263.

Trabaud L., 1980. Impact biologique et écologique des feux de végétation sur l'organisation, la structure et l'évolution de la végétation des garrigues du Bas-Languedoc (Biological and ecological impact of fire on vegetation organization, structure and evolution in the 'garrigues of Bas-Languedoc). Thèse Doct. Etat. Univ. Sci. Tech. Languedoc, Montpellier (in French).

Trabaud, L., 1987. Fire and survival traits of plants. In: Trabaud, L. (Ed.), The Role of Fire in Ecological Systems. SPB Academic Publishing, Hague, pp. 65-89.

Trabaud, L., 1995. Modalités de germination des cistes et des pins méditerranéens et colonisation des sites perturbés (Types of germination in Mediterranean's Cistus and Pinus and perturbed zones colonization). Rev. Ecol. (Terre Vie) 50, 3-14 (in French with English summary).

Trabaud, L., Renard, P., 1999. Do light and litter influence the recruitment of Cistus spp. stands? Israel J. Plant Sci. 47, 1-9.

Tutin, T.G., Heywood, V.H., Burges, D.H., Valentine, D.H., Moore, D.M., Walters, S.M., Webb, D.A., 1964-1980. Flora Europaea. Cambridge University Press, Cambridge.

Valbuena, L., Tárrega, R., Luis, E., 1992. Influence of heat on seed germination of Cistus laurifolius and Cistus ladanifer. Int. J. Wildland Fire 2, 15-20.

Valbuena, L., Calvo, L., Santalla, S., Tárrega, R., De Luis-Calabuig, E. 2002. Contribution of the seed bank to the regeneration of a community of Pinus pinaster. Abstracts of Medpine 2. Chaina, Creta, 70 pp.

Van Wagner, C.E., 1983. Conditions for the start and spread of crown fire. Can. J. For. Res. 7, 23-24.

Velez, R., 2000. La defensa contra incendios forestales. Fundamentos y experiencias (Forest fire prevention. Principles and experiences). McGraw-Hill, Madrid (in Spanish). 